Харченко Євген Миколайович, доктор медичних наук, професор, завідувач відділу психіатрії станів залежності ДУ «Інститут психіатрії МОЗ України», Київ, Україна; kharchenko.yevh@gmail.com

ORCID ID 0000-0002-4340-8503

Древіцька Оксана Остапівна, доктор медичних наук, доцент, завідувач кафедри медичної психології ПрАТ «ВНЗ «Міжрегіональна Академія управління персоналом»; 02000, вул. Фрометівська, 2, м. Київ, Україна; drevitska@ukr.net; +38 (067) 702-45-90

ORCID ID 0000-0002-1551-9329

Сиропятов Олег Геннадійович, доктор медичних наук, професор, завідувач відділу медико-соціальних проблем терапії психічних розладів ДУ «Інститут психіатрії MO3 України», м. Київ, Україна; ndips@ukr.net

ORCID ID 0000-0002-1177-3127

Мажбіц Валентина Борисівна, кандидат медичних наук, науковий співробітник відділу психосоматичної медицини та психотерапії ДУ «Інститут психіатрії MO3 України», Київ, Україна; mazhbitc@gmail.com

ORCID ID 0000-0002-1177-7283

Михальчук Наталія Олександрівна, доктор психологічних наук, професор, завідувач кафедри практики англійської мови Рівненського державного гуманітарного університету, Рівне, Україна; Natasha1273@ukr.net

ORCID ID 0000-0003-0492-9450 


\title{
ХАРАКТЕРИСТИКА КЛІНІЧНОЇ СИМПТОМАТИКИ ПРИ ПСИХОТИЧНИХ РОЗЛАДАХ У КОМБАТАНТІВ
}

\begin{abstract}
Анотація
Харченко Свген Миколайович, доктор медичних наук, професор, завідувач відділу психіатрії станів залежності ДУ «Інститут психіатрії МОЗ України», м. Київ, Україна; Древіцька Оксана Остапівна, доктор медичних наук, доцент, завідувач кафедри медичної психології ПрАТ «ВНЗ «МАУП», м. Київ, Україна; Сиропятов Олег Геннадійович, доктор медичних наук, професор, завідувач відділу медико-соціальних проблем терапії психічних розладів ДУ «Інститут психіатрії МО3 України», м. Київ, Україна; Мажбіц Валентина Борисівна, кандидат медичних наук, науковий співробітник відділу психосоматичної медицини та психотерапії ДУ «Інститут психіатрії MO3 України, м. Київ, Україна; Михальчук Наталія Олександрівна, доктор психологічних наук, професор, завідувач кафедри практики англійської мови Рівненського державного гуманітарного університету, м. Рівне, Україна. Характеристика клінічної симптоматики при психотичних розладах у комбатантів.
\end{abstract}

Ключові слова: психотичні розлади, клінічна симптоматика, комбатанти.

Постановка проблеми. Участь у військових операціях викликає високу частоту психогенних порушень, які, у свою чергу, можуть бути пусковим чинником виникнення психозів. Оцінка структури, особливостей формування, маніфестації, симптоматики та перебігу психотичних розладів у комбатантів сприятиме розробці відповідних заходів їх психопрофілактики і лікування.

Формулювання мети статті. Мета - дослідити клінічну симптоматику при психотичних розладах у комбатантів. 
Виклад основного матеріалу. Проведено аналіз 64 історій хвороб комбатантів, які перенесли психози та лікувалися в психіатричних стаціонарах. За даними медичної документації було досліджено структуру психотичних розладів, симптоматику при госпіталізації. Обробку отриманих даних проводили за критерієм $\chi^{2}$.

Результати аналізу 64 історій хвороб показали, що у більшості пацієнтівкомбатантів, які лікувалися стаціонарно в психіатричних установах, були виставлені наступні основні діагнози: шизофренія (F20) - у 28 осіб, шизотипові розлади (F21) - у 4 осіб, гострі та транзиторні психотичні розлади (F23) - у 25 осіб, шизоафективні розлади (F25) - у 7 осіб. У 38 (59,4\%) комбатантів психотичні розлади розпочиналися гостро, після перенесеної психотравми, тоді як у решти осіб поступово посилювалися розлади психіки і поведінки, які унеможливлювали їх подальшу військову службу. Розлади мислення, маячні ідеї та неадекватний афект переважали в структурі психопатологічної симптоматики. У проявах маячних розладів та афективних реакцій спостерігалися переживання, які були пов'язані з військовими операціями, травмами та смертельними випадками однополчан у 47 комбатантів (72,3\%). Коморбідні до психотичних розладів окремі симптоми i розгорнута симптоматика ПТСР до початку лікування мала місце у 52 осіб (81,3\%).

Висновки і перспективи подальших досліджень. Здійснено аналіз поширеності та структури психотичних розладів у комбатантів за аналізом медичної документації. Досліджено нозологічний спектр, маніфестацію, характеристику клінічної симптоматики при шизофренії й гострих та транзиторних психотичних розладах. 


\section{Аннотация}

Харченко Евгений Николаевич, доктор медицинских наук, профессор, заведующий отделом психиатрии состояний зависимости ГУ «Институт психиатрии MO3 Украины», г. Киев, Украина; Древицкая Оксана Остаповна, доктор медицинских наук, доцент, заведующая кафедрой медицинской психологии ЧАО «ВУЗ «МАУП», г. Киев, Украина; Сыропятов Олег Геннадьевич, доктор медицинских наук, профессор, заведующий отделом медико-социальных проблем терапии психических расстройств Д ГУ «Институт психиатрии МОЗ Украины», г. Киев, Украина; Мажбиц Валентина Борисовна, кандидат медицинских наук, научный сотрудник отдела психосоматической медицины и психотерапии ГУ «Институт психиатрии МО3 Украины», г. Киев, Украина; Михальчук Наталия Александровна, доктор психологических наук, профессор, заведующая кафедрой практики английского языка Ровенского государственного гуманитарного университета, г. Ровно, Украина. Характеристика клинической симптоматики при психотических расстройствах у комбатантов.

Ключевые слова: психотические расстройства, клиническая симптоматика, комбатанты.

Постановка проблемы. Участие в военных операциях вызывает высокую частоту психогенных нарушений, которые, в свою очередь, могут быть пусковым фактором возникновения психозов. Оценка структуры, особенностей формирования, манифестации, симптоматики и течения психотических расстройств у комбатантов будет способствовать разработке соответствующих мер их психопрофилактики и лечения.

Формулировка цели работы: Цель - исследовать клиническую симптоматику при психотических расстройствах у комбатантов. 
Изложение основного материала. Материалы и методы исследования. Проведен анализ 64 историй болезней комбатантов, перенесших психозы и лечившихся в психиатрических стационарах. По данным медицинской документации были исследованы: структура психотических расстройств, симптоматика при госпитализации. Обработку полученных данных проводили по критерию $\chi^{2}$.

Результаты анализа 64 историй болезней показали, что у большинства пациентов-комбатантов, которые лечились стационарно в психиатрических учреждениях, были выставлены следующие основные диагнозы: шизофрения (F20) - у 28 пациентов, шизотипические расстройства (F21) - у 4 человек, острые и преходящие психотические расстройства (F23) - у 25, шизоаффективные расстройства (F25) - у 7 пациентов. У 38 (59,4\%) комбатантов психотические расстройства начинались остро, после перенесенной психотравмы, тогда как у остальных лиц постепенно усиливались расстройства психики и поведения, исключающие их дальнейшую военную службу. Расстройства мышления, бредовые идеи и неадекватный аффект преобладали в структуре психопатологической симптоматики. В проявлениях бредовых расстройств и аффективных реакций наблюдались переживания, которые были связаны с военными операциями, травмами и смертельными случаями однополчан у 47 комбатантов (72,3\%). Коморбидные к психотическим расстройствам отдельные симптомы и развернутая симптоматика ПТСР до начала лечения имела место у 52 пациентов $(81,3 \%)$.

Выводы и перспективы дальнейших исследований. Осуществлен анализ распространенности и структуры психотических расстройств у комбатантов с помощью анализа медицинской документации. Исследованы: нозологический спектр, манифестация психозов, проведен подробный сравнительный анализ клинической симптоматики при наиболее часто 
встречающихся психозах: шизофрении (F20), острых и транзиторных психотических расстройствах (F23).

\section{Annotation}

Kharchenko Y. M., PhD, MD, Professor, Head of the Department of Addiction Psychiatry, Institute of Psychiatry, Ministry of Health of Ukraine, Kyiv, Ukraine; Drevitska O. O., PhD, MD, Associate Professor, Head of the Medical Psychology Department, The Private Joint-Stock Company "Higher Educational Institution "Interregional Academy of Personnel Management"; Kyiv, Ukraine; Syropyatov O. H., PhD, MD, Professor, Head of the Department of Medical and Social Problems of Therapy of Mental Disorders of the Institute of Psychiatry of the Ministry of Health of Ukraine, Kyiv, Ukraine; Mazhbits V. B., PhD, Research Fellow, Department of Psychosomatic Medicine and Psychotherapy, Institute of Psychiatry, Ministry of Health of Ukraine, Kyiv, Ukraine; Mykhalchuk N. O., Doctor of Psychological Sciences, Professor, Head of the Department of English Language Practice, Rivne State University for the Humanities, Rivne, Ukraine. Characteristics of Clinical Symptoms of Psychotic Disorders of Combatants.

Keywords: psychotic disorders, clinical symptoms, combatants

Formulation of the problem. Participation in hostilities causes to a high incidence of psychogenic disorders, which can be a reason for psychosis. Assessment of the structure, features of the formation, the manifestation, symptoms of psychotic disorders of combatants will contribute to the development of appropriate measures of their psychoprophylaxis and treatment.

Analysis of recent research and publications. In conditions of local armed conflict, combat mental trauma (pathological state of the central nervous system of prenosological level, caused by combat stress factors) can increase mental illnesses 3 4 times and reduce the combat capability of servicemen within 10 to $50 \%$. World 
statistics shows that each fifth combatant suffers from neuropsychiatric disorders when there is no any physical damage. According to statistics of different countries, from $6,6 \%$ to $12,7 \%$ of military men are discharged due to mental disorders, which is about $30 \%$ of all diseases in the army. However, during periods of active fighting up to $15-25 \%$ of personnel suffer from various mental disorders.

Formulating the purpose of the article. Objective: to investigate the clinical symptomatology of psychotic disorders of combatants.

Material and methods. 64 cases of stories of combatants who underwent psychosis and were treated in psychiatric hospitals had been analyzed. According to the medical records there were investigated: the structure of psychotic disorders, symptoms during hospitalization. The data obtained were processed according to the criterion $\chi^{2}$.

Results. The analysis of 64 medical cases showed that the majority of combatant, who had their treatment at psychiatric hospitals, the following diseases had been diagnosed: schizophrenia (F20) - 28 persons, schizotypical disorders (F21) - 4 persons, acute and transient psychotic disorders (F23) - 25 persons, schizoaffective disorders (F25) - 7 persons. 38 (59,4\%) patients had the situation when psychiatric disorders began acutely after some trauma, while the rest of the persons gradually were increased by their mental disorders and behavior, which precluded their further military service. Thinking disorders, delusional ideas and inadequate affect were predominated in the structure of psychopathological symptoms. The manifestations of delusional disorders and affective reactions were associated with military operations, injuries and fatalities of some combatants (there are 47 combatants $(72,3 \%))$. Comorbid to psychotic disorders were individual symptoms or advanced post-traumatic stress disorder (PTSD) symptoms to the beginning of treatment (52 patients $(81,3 \%)$. 
Conclusions and prospects for further research. An analysis of the prevalence and structure of psychotic disorders in combatants on the analysis of

medical records was carried out. Investigated: nosological spectrum, manifestation of psychoses, detailed comparative analysis of clinical symptoms in the most common psychoses: schizophrenia (F20) and acute and transient psychotic disorders (F23).

\section{CHARACTERISTICS OF CLINICAL SYMPTOMS OF PSYCHOTIC DISORDERS OF COMBATANTS}

Keywords: psychotic disorders, clinical symptoms, combatants

Formulation of the problem. The problem of psychiatric disorders of combatants: their structure, features, mechanisms of formation - is one of the most actual and least developed issues of clinical psychiatry. Participation in hostilities causes to a high incidence of psychogenic disorders, which can be a reason for psychosis. Assessment of the structure, features of the formation, the manifestation, symptoms of psychotic disorders of combatants will contribute to the development of appropriate measures of their psychoprophylaxis and treatment.

Analysis of recent research and publications. In conditions of local armed conflict, combat mental trauma (pathological state of the central nervous system of prenosological level, caused by combat stress factors) can increase mental illnesses 34 times and reduce the combat capability of servicemen within 10 to $50 \%$. World statistics shows that each fifth combatant suffers from neuropsychiatric disorders when there is no any physical damage $[1-3,5]$.

According to statistics of different countries, from $6,6 \%$ to $12,7 \%$ of military men are discharged due to mental disorders, which is about $30 \%$ of all diseases in the 
army. However, during periods of active fighting up to $15-25 \%$ of personnel suffer from various mental disorders [4, 7-9].

Ukrainian servicemen who are in the area of fighting carry a special burden of prolonged extraordinary psycho-emotional load, which often results in signs of psychiatric disorders, for example, post-traumatic stress disorders, disorders of the depressive circle, which can provoke manifestations of psychotic disorders [1, 4-5] .

The scientists separate acute period of mental disorders, which includes acute and transient mental disorders of varying severity of each person. These people haven't previously had any psychiatric disorders, in response to exceptional physical and psychological stress lasting several hours or days. However, at first, when the person has treatment at the hospital it is difficult to differentiate this psychological stress with the possible development of schizophrenia [1, 5-8].

Features of psychotic symptoms of combatants can be caused not only by psychogenic effects, but also by somatic pathology, injuries, and traumatic brain injuries because of the war [7-9].

Particular attention we have to pay for studying of the symptoms of the psychotic registry, because the military is a special contingent who need increased social attention in a case of illness with psychosis, since the presence of their military experience can pose a threat to the lives and health of the patients themselves, their relatives and their social environment.

Assessment of the structure, features of the formation, manifestation, clinical and psychopathological explications of psychotic disorders of combatants will contribute to the development of appropriate measures of their psychoprophylaxis and treatment.

Formulating the purpose of the article. Objective: To investigate the characteristics of clinical symptoms of the most common psychotic disorders of combatants. 
The tasks of our research:

- to analyze the frequency of various psychotic disorders of combatants. who were treated in a psychiatric department of the hospital;

- to study of the symptoms of the most common mental disorders of combatants;

- to analyze of typicality and specificity of symptomatology of combatants with psychosis.

The presentation of the main material. Material and methods of research: 64 cases of illnesses and their treatment of combatants who had psychosis and were treated at psychiatric hospitals were analyzed. According to medical data, the structure of psychotic disorders, symptoms at the beginning of inpatient treatment were investigated. Statistical analyses of empiric data was done with the help of $\chi^{2}$ criterion.

Results. The analysis of the cases of illnesses and their treatment of combatants with acute psychotic symptoms (64 male patients) who were on inpatient treatment at psychiatric hospitals had some certain features. For example, patients from 19 to 58 years old $(59 ; 92,2 \%)$ were participated in our research; the average age of the soldiers was 25-30 years old.

The results of our research showed that patients $(41,64,1 \%)$ with secondary special education were predominant among all patients. At the same time, 12 patients $(18,8 \%)$ had higher education and only 6 respondents $(9,4 \%)$ hadn't higher education (or it was incompleted).

The research showed that $1 / 3$ of patients $(19 ; 29,7 \% ; p<0,05)$ had more than 10 years of professional experience. The most amount of men $(44 ; 68,9 \% ; p<0.05)$ have had their own families.

The results of the analysis of 64 cases of illnesses and their treatment showed that inpatients at psychiatric hospitals had been diagnosed with the following diagnoses: schizophrenia (F20) - 28 persons (43,75\%), schizotypical disorders (F21) 
- 4 persons $(6,25 \%)$, acute and transient psychotic disorders (F23) - in 25 patients $(39,1 \%)$, schizoaffective disorders (F25) - 7 respondents (10,9\%) patients.

38 patients $(59,4 \%)$ had psychotic disorders which had begun acutely after some trauma, while the rest of the patients had had disorders of the psyche and behavior which had begun gradually. The last made it impossible for them to continue their military service.

Some features of premorbid were observed in a case when patients had schizophrenia: selectivity of communication, limited emotional attachments (29 patients $(45,3 \%))$; often in premorbid there had been a special affection for one of the relatives and rejection of others - such patients there were $25(39,1 \%)$.

The most significant provoking manifestation of acute psychosis were mental traumas, such as emotional deprivation. In such kinds of situations the patients lost the usual for them support, which led to the development of alarming symptoms, to uncertainty and experience of danger. This, at first, gave risen psychogenic problems, and then some procedural anxiety, suspicion and hallucinatory-dreamy symptoms.

Because inpatient combatants were most often diagnosed with schizophrenia $44 \%$ of respondents, and patients who had acute and transient psychotic disorders $39 \%$ of them, a comparative analysis of symptoms of them was done.

The analysis of the main groups of patients with psychotic disorders showed that at the stage of hospitalization and before the effects of treatment with psychotropic drugs patients had symptoms of a psychotic circle: disorders of contact, disorders of thinking, emotional and volitional disorders, motor and behavioral ones. The main symptoms and their frequency are shown in Tables 1-3.

Table 1.

Disorders of contact, general state of patients at the movement of hospitalization

\begin{tabular}{|c|c|c|}
\hline & Patients with & Patients with acute and transient \\
Symptoms & schizophrenia (F20) & psychotic disorders (F23) \\
& $\mathrm{N}=28$ & $\mathrm{~N}=25$ \\
\hline
\end{tabular}




\begin{tabular}{|l|c|c|c|c|}
\hline & amount & $\%$ & Amount & $\%$ \\
\hline Sleep disorders & 23 & 82,1 & 18 & 72,0 \\
\hline Autism & 12 & 42,8 & 4 & 28,0 \\
\hline Negativism in & 21 & $75,0^{*}$ & 9 & 12,0 \\
\hline $\begin{array}{l}\text { Indifference } \\
\text { appearance, } \\
\text { carelessness }\end{array}$ & 15 & $53,6^{*}$ & 3 & $16,0^{*}$ \\
\hline Confusion & 8 & $28,6^{*}$ & 16 & $64,0^{*}$ \\
\hline $\begin{array}{l}\text { Motor } \\
\text { Inhibition }\end{array}$ & & & 3 & 12,0 \\
\hline
\end{tabular}

- $-\mathrm{P}<0,05$, according to the criterion $\chi^{2}$.

As we can see from the results of Table 1, patients with schizophrenia had motor inhibition, indifference to their appearance, they were characterized by carelessness, whereas the state of confusion had prevailed in a case of acute and transient psychotic disorders, such differences in symptomatology we'll show by Fig. 1.

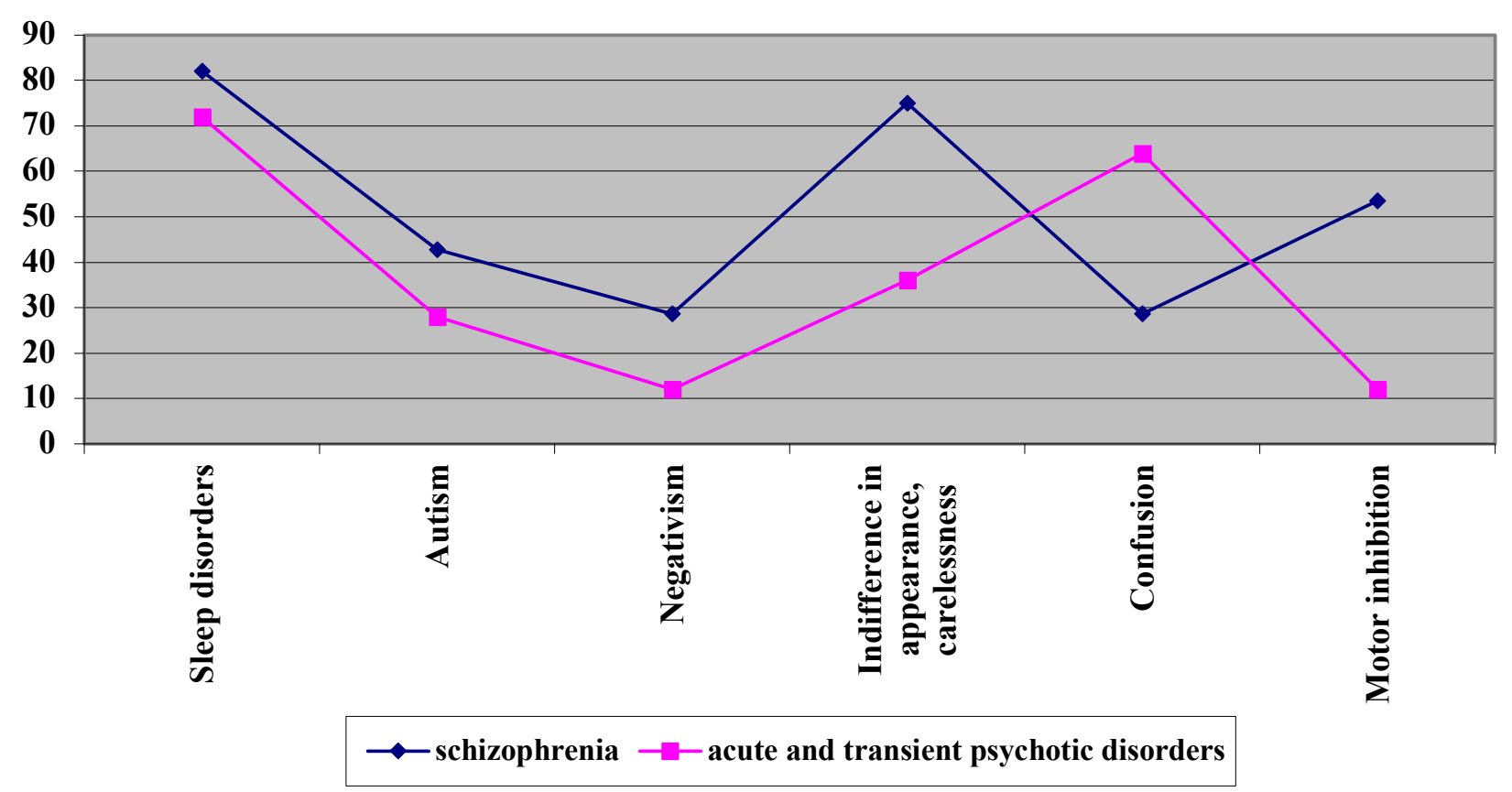


Fig. 1. Frequency (in \%) of a number of symptoms in a case of schizophrenia (F20) and acute and transient psychotic disorders (F23)

It should be noted that motor disorders of patients were unstable: motor inhibition was alternated with periods of unmotivated psychomotor excitation, with elements of aggression in expressions and behavior of respondents.

Patients with schizophrenia in the period before the beginning of their treatment with the help of psychotropic drugs also more often had: periodic arousal, unmotivated aggression, and in the process of communication we often noted their emotional impoverishment, lack of syntonity in emotional responses (Table 2, Fig. 2).

The most amount of patients had a bad (lowered) mood, such as 78,6\% patients with schizophrenia and $68 \%$ of patients with acute and transient psychotic disorders. Unmotivated depressive state was more commonly observed in a case of patients with schizophrenia: patients did not explain the cause of this mood, whereas respondents with acute and transient psychotic disorders explained the real events they had experienced during the fighting or due to deteriorating of relationships with relatives.

Table 2.

Emotional disorders of patients at the moment of hospitalization

\begin{tabular}{|l|c|c|c|c|}
\hline \multirow{2}{*}{ Symptoms } & \multicolumn{2}{c|}{$\begin{array}{c}\text { Patients with } \\
\text { schizophrenia (F20) } \\
\text { N =28 }\end{array}$} & \multicolumn{2}{c|}{$\begin{array}{c}\text { Patients with acute and } \\
\text { transient psychotic disorders } \\
\text { (F23) N=25 }\end{array}$} \\
\cline { 2 - 5 } & amount & $\%$ & amount & $\%$ \\
\hline Fear, anxiety & 18 & 64,3 & 12 & 48,0 \\
\hline Low mood & 22 & 78,6 & 17 & 68,0 \\
\hline Excitation & 18 & 64,3 & 8 & 36,0 \\
\hline Aggression & 12 & 42,8 & 7 & 28,0 \\
\hline Mood swings & 20 & 71,4 & 19 & 76,0 \\
\hline $\begin{array}{l}\text { Emotional } \\
\text { impoverishment }\end{array}$ & 20 & $71,4^{* *}$ & 7 & $28,0^{* *}$ \\
\hline
\end{tabular}


** $-\mathrm{P}<0,01$, according to the criterion $\chi^{2}$.

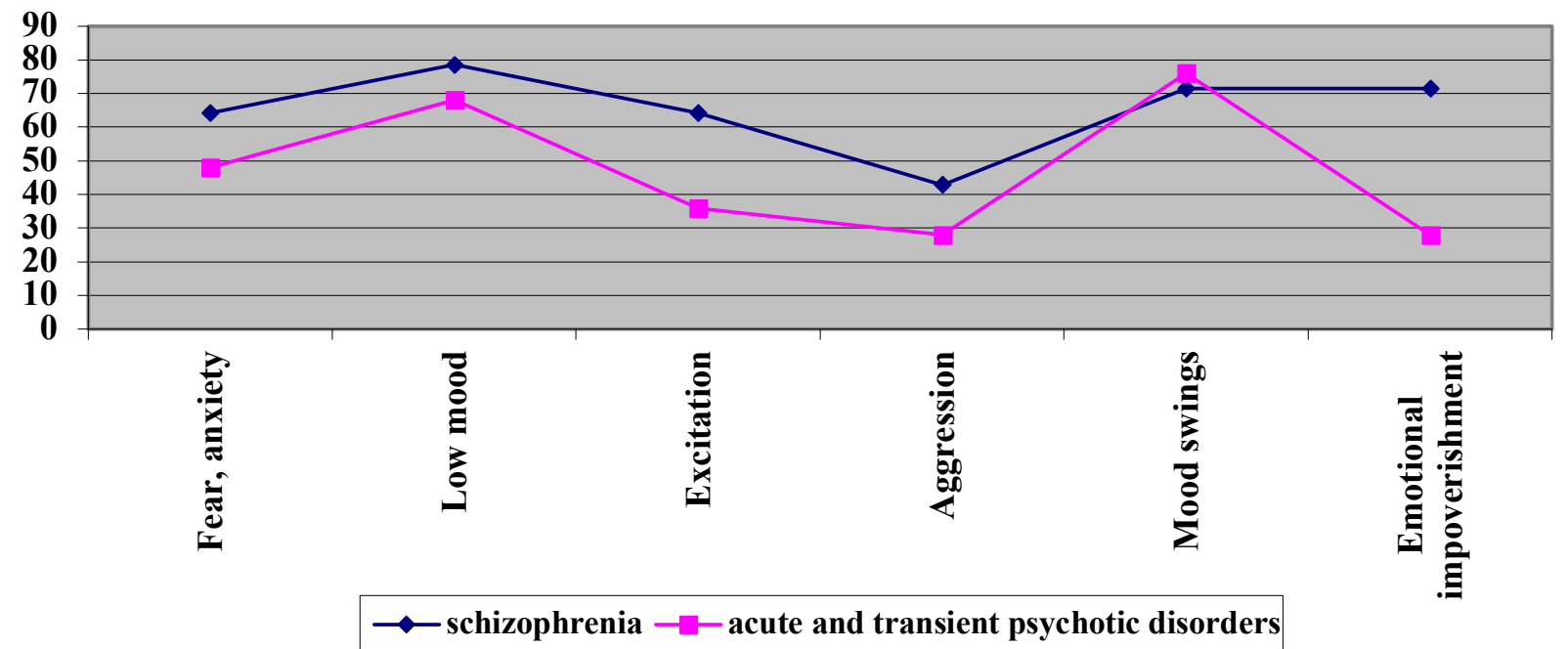

Fig. 2. Frequency (in \%) of symptoms of emotional disorders in cases of schizophrenia (F20) and acute and transient psychotic disorders (F23)

Emotional disorders of patients with psychosis were different. As we can see from Table 2, low mood was combined with other disorders. Patients with schizophrenia often had: emotions of fear, increased anxiety. Their emotions were often "detached" from the statements and suggestions of these patients. Emotions were unmotivated, while patients with acute and transient psychotic disorders more often expressed fear and anxiety when they described their state.

Comparison of symptoms of emotional disorders shows that the absence of emotional impoverishment in a great degree was more characterized patients with schizophrenia, as well as cognitive disorders, that is clearly shown in Table. 3 and Fig. 3.

Table 3.

Disorders of perception, thinking and speech of patients with psychoses

\begin{tabular}{|c|c|c|}
\hline Symptoms & Patients with schizophrenia & Patients with acute and \\
& $(\mathrm{F} 20)$ & transient psychotic disorders \\
& $\mathrm{N}=28$ & (F23) $\mathrm{N}=25$ \\
\hline
\end{tabular}




\begin{tabular}{|l|c|c|c|c|}
\hline & amount & $\%$ & amount & $\%$ \\
\hline $\begin{array}{l}\text { Voices in patient's } \\
\text { head }\end{array}$ & 21 & $75,0^{* *}$ & 8 & $32,0^{* *}$ \\
\hline False recognitions & 5 & $17,6^{*}$ & 12 & $48,0^{*}$ \\
\hline $\begin{array}{l}\text { Interruption of } \\
\text { thoughts }\end{array}$ & 26 & $92,9^{* *}$ & 12 & $48,0^{* *}$ \\
\hline $\begin{array}{l}\text { Ideas of influences } \\
\text { on thoughts }\end{array}$ & 23 & $82,1^{* *}$ & 9 & $36,0^{* *}$ \\
\hline $\begin{array}{l}\text { Looming } \\
\text { persecution }\end{array}$ & 21 & $75,0^{*}$ & 12 & $48,0^{*}$ \\
\hline $\begin{array}{l}\text { Non-critical } \\
\text { thinking }\end{array}$ & 26 & $92,9^{* *}$ & 14 & $56,0^{* *}$ \\
\hline Poverty of speech & 25 & $89,3^{*}$ & 16 & $32,0^{*}$ \\
\hline Neologisms & 23 & $82,1^{* *}$ & 11 & $44,0^{* *}$ \\
\hline
\end{tabular}

$*-\mathrm{P}<0,05, \quad * *-\mathrm{P}<0,01$ according to the criterion $\chi^{2}$.

Probably more often such symptoms as: "voices in someone's head", "interruption of thoughts", "ideas of influences on thoughts", "looming persecution", "poverty of speech" and "neologisms" had patients with a diagnosis of "schizophrenia", while "false recognitions" and a state of confusion more often had patients with acute and transient psychotic disorders.

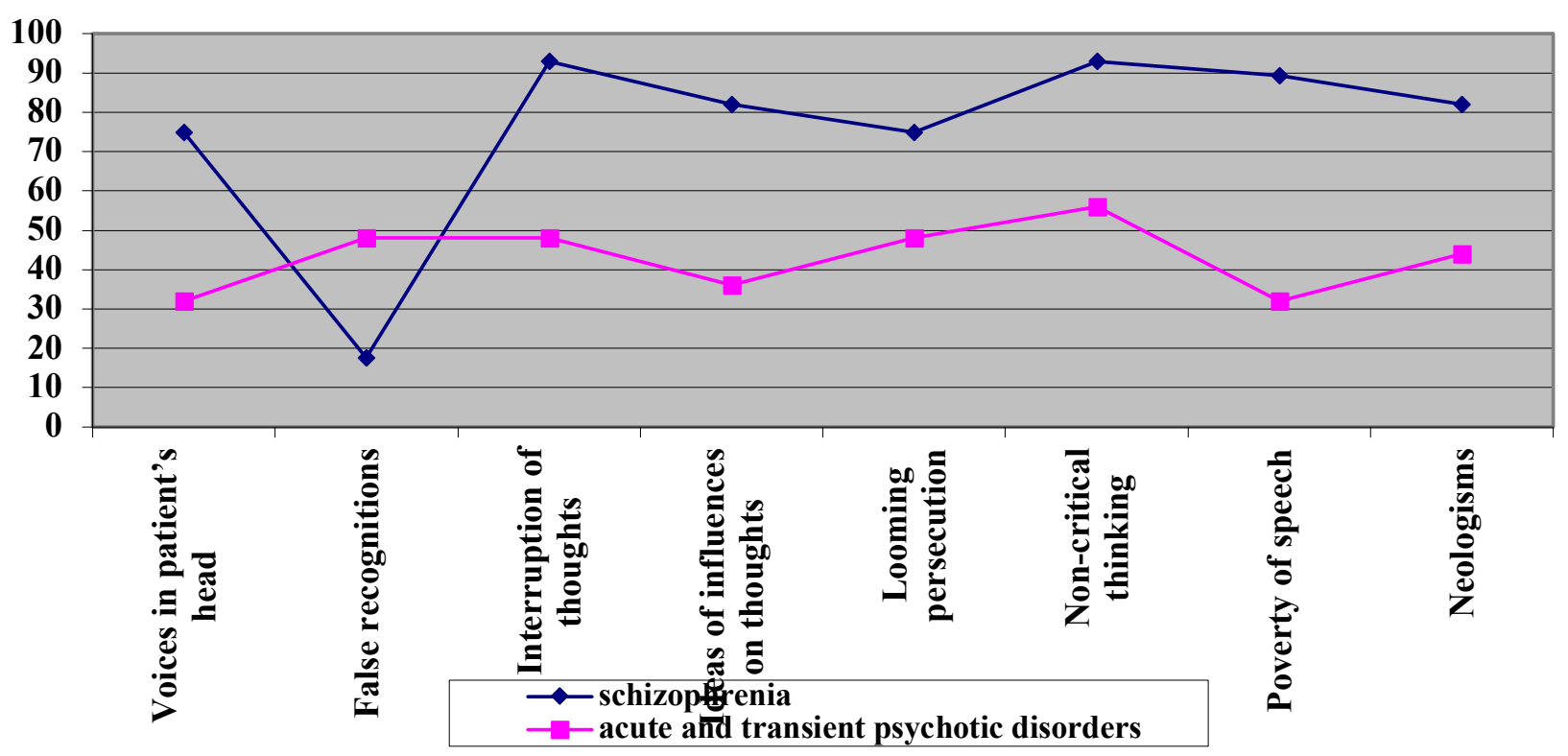


Fig. 3. Frequency (in \%) of symptoms of cognitive disorders in cases of schizophrenia (F20) and acute and transient psychotic disorders (F23)

In a case of acute and transient psychotic disorders under the influence of mental trauma, psychotic disorders became polymorphic and variable in nature, coexisted with neurotic symptoms. But in a case of schizophrenia the symptoms did not go beyond the hallucinatory-mare registry, there was only the inclusion of psychogenic changes. Manifestations of endogenous psychosis have become more classic.

Hallucinations in a case of acute and transient psychotic disorders have often been associated with people and events which have done psychologically injured effect on patients. Their delusional production has also reflected the content of psychotrauma.

The pathoplastic effect of psychotrauma, which was determined at the stage of initiation schizophrenic psychosis, had decreased or stopped completely. The result of this was in falling out the psycho-traumatic event from the storyline of psychotic experiences. The most amount of patients have had endoreactive psychosis until its complete reduction. In these cases, as the endogenous attacks have progressed, both in a case of endoreactive, independent and pathoplastic variants of endogenous and psychogenic disorders, there was a psychopathological "shift" towards a typical disorder of a particular form of psychosis.

Thus, the analysis of the symptoms in cases of schizophrenia (F20) and acute and transient psychotic disorders (F23) showed that some patients who had been diagnosed with F23 after treatment because of re-hospitalization were marked with F20. But during the first psychotic period they had been more made "softer" diagnosis, and that had reduced the level of stigmatization of patients and could facilitate their social adaptation for a certain period of time. 
Among the symptoms of all 64 patients with psychosis disorders of thinking were dominated. These disorders were different: in content, by their form, violations of abstract thinking, there were observed stereotyped statements, lack of judgment and criticism of their own statements. Inadequacy of thinking was combined with inadequacy of behavior, emotional and volitional disorders.

Thinking disorders were also combined with depressive circle symptoms (39 $(60,9 \%)$ patients), maniacally similar affect was only observed in 15,6\% (10 patients), and psychopathic symptoms had 19 respondents $(29,7 \%)$.

The content of delusional thinking disorders and affective reactions was related to military operations, injuries and deaths during military operations in $72,3 \%$ cases (47 military men with various psychotic disorders). Comorbid to psychotic disorders, some symptoms and widespread symptoms of PTSD before the beginning of treatment were in $81,3 \%$ of cases ( 52 people).

Situation of emotional deprivation $(62,5 \%)$ played a significant role in the formation of psychotic disorders. In situations where it was the loss of a close friend or a colleague, firstly affective shocks appeared, after them in a few days there was psychogenic depression, and then there were observed affective and delusional psychoses with polymorphic symptoms or psychoses with inverse maniacal affect and paraffin delusions.

In $15,6 \%$ cases (10 patients) there was an inadequate paradoxical reaction to the situation of life threat, manifested by maniacal affect and expansive delirium, when patients spoke about their special purpose in the fight against the enemy, in the creation of new means, devices that will make a person immortal, when they planned to make all the humanity happy.

Mixed affective state was often a reflection of variable in the intensity of psychologically traumatic circumstances. Some patients explained their "rise" in a 
state of maniacal affect, as a divine uplift that, according to the patients, kept them from inevitable death during the fighting.

According to the results of our research, we have to fix and note probable difficulties of microsocial and social adaptation of sick combatants. Although about $70 \%$ of sick men had a family $(44 ; 68,9 \%)$, only half of them $(34 ; 53,1 \%)$ wanted to continue to live in their families, and $27(42,1 \%)$ of patients complained on difficult relationships with family members.

According to professional adaptation, it should be noted that only 32 patients (50\%) had a positive social outlook after hospital discharge, and another 16 among them $(25,0 \%)$ were recommended to have the 3rd group of disability. This factor shows us further difficulties in social adaptation of $75 \%$ of combatants with psychosis.

Therefore, speaking about the difficulties of family and professional adaptation of combatants who have suffered of psychosis, we have to emphasize that social and psychological rehabilitation at the place of their residence, the creation of special programs for such patients, is of particular importance for them.

\section{Conclusions and prospects for further research.}

1. The prevalence and the structure of psychotic disorders of combatants treated at the hospital were analyzed. Psychoses of these patients were the most often presented by such diagnoses: schizophrenia - 28 patients $(43,75 \%)$, acute and transient psychotic disorders -25 respondents (39,1\%); schizoaffective disorders (F25) - 7 ones $(10,9 \%)$, schizotypical disorders (F21) - 4 patients $(6,25 \%)$.

2. The manifestation of such a disease was acute in $59,4 \%$ cases (38 patients) after psychotic trauma, while the rest of the individuals gradually had disorders of the psyche and behavior that made it impossible for them to continue military service.

3. At the time of hospitalization at the hospital, all patients had emotional and volitional disorders and disorders of thinking: in a content, in a form, abstract thinking 
disorders, stereotypical statements, lack of judgment, criticism of their own statements and suggestions.

4. Thinking disorders were combined with affective disorders of the depressive circle (39 patients $(60,9 \%))$, maniacal affect took a place in $15,6 \%$ of cases $(10$ patients), psychopathic symptoms had 19 respondents (29,7\%).

5. The symptoms in a case of schizophrenia (F20) and acute and transient psychotic disorders (F23) were differed, mainly at the level of the explication of cognitive sphere. In a case of schizophrenia symptoms (such as "voices in the head", interruptions of thoughts, ideas of influence on thoughts, delusions of persecution, non-critical thinking, poverty of speech and neologisms) were more often to be observed. We have to emphasize that false recognition on the background of the state of confusion took a place more often when patients were confused and when respondents had transient psychotic disorders.

6. Individual symptoms which were comorbid to psychotic disorders and widespread symptoms of PTSD till the beginning of the treatment took a place in $81.3 \%$ of cases (52 people). Difficulties in relations with family and friends were noted by the majority of patients, and in $75 \%$ of cases there was a decrease of the level of capacity of their professional activity, which indicated the importance of continuing the social and psychological rehabilitation of such a contingent of patients after hospital discharge.

Perspectives for further researches are related with a detailed study of clinical and psychopathological phenomenology and comorbidity of psychotic disorders of combatants using a wide range of psychodiagnostic techniques.

The similarity of the clinical picture of the most common psychosis of combatants indicated a possible change in the diagnosis of "acute and transient psychotic disorders (F23)" of some patients with the diagnosis of "schizophrenia 
(F20)" with further exacerbation of the disease and deepening social disadaptation of these patients.

Our research points out the importance of further follow-up researches with the aim to develop recommendations for correct diagnosis and for appropriate treatment and rehabilitation. The presence of additional psycho-traumatic factors requires the use of specific approaches to psychological correction and psychotherapy in the process of rehabilitation.

Based on these empirical researches, we plan to develop individualized approaches to prevention, treatment and rehabilitation of psychotic disorders of sick military personnel who have suffered by a psychotic episode.

\section{Список використаних джерел}

1. Волошин П. В. Посттравматичні стресові розлади: проблеми лікування и профілактики / Волошин П. В., Шестопалова Л. Ф., Підкоритов В. С. // Міжнародний медичний журнал, 2004.- Т. 10.- № 1.- С. 33-37.

2. Михайлов Б. В. Принципи психотерапії і фармакотерапії розладів психіки i поведінки екстремально-психогенного походження / Б. В. Михайлов // Міжнародний психіатричний, психотерапевтичний та психоаналітичний журнал, 2015.- Т. 8.- № 3 (29).- С 4-14.

3. Семигіна Т. Охорона психічного здоров'я в умовах війни: у 2-х т. / Семигіна Т., Павленко І., Овсяннікова Є. - К.: Наш формат, 2017.-Т.1-568 с.

4. Охлопкова Т. Охорона психічного здоров'я в умовах війни: у 2-х т./ Охлопкова Т., Бацюк Т.- К.: Наш формат,2017.-Т.2.-548 с.

5. Пінчук І. Я. Оптимізація підходів до надання психіатричної допомоги відповідно до сучасних потреб учасників бойових дій: метод. рекомендації / Пінчук І. Я., Хаустова О.О.- К., 2014.- 47 с. 
6. Spinhoven, P., Penninx, B.W., van Hemert, A.M., de Rooij, M., \& Elzinga, B.M. (2014). Comorbidity of PTSD in anxiety and depressive disorders: Prevalence and shared risk factors. Child abuse \& neglect, 38(8), pp.1320-1330.

7. Patel, M.B., Jackson, J.C., Morandi, A., Girard T.D. (2016). Incidence and Risk Factors for ICU-related Posttraumatic Stress Disorder in Veterans and Civilians. AJRCCM. article in press. - retrieved from: http://www.atsjournals.org/doi/abs/ 10.1164/rccm.201506-1158OC\#.WBi0j3V97eQ

8. War Trauma Foundation and World Vision International (2010). Psychological First Aid Anthology of Resources. Downloadable from: www.interventionjournal. com/ and www.psychosocialnetwork.net.

9. World Health Organization (2010). mhGAP Intervention Guide for Mental Health, Neurological and Substance Use Disorders in Non-specialized Health Settings. Geneva: WHO Mental Health Gap Action Programme. http://www. who.int/mental_health/mhgap.

\section{References}

1. Voloshyn, P. V. Shestopalova, L. F. Podkorytov6 V. S. (2004), "Posttraumatic stress disorders: problems of treatment and prevention", Mezhdunarodny medytsynsky zhurnal, vol. 10 (1), pp. 33-37, Ru.

2. Mykhailov, B.V. (2015). "Principles of psychotherapy and pharmacotherapy of disorders of the psyche and behavior of extreme psychogenic origin", Mizhnarodnyi psykhiatrychnyi, psykhoterapevtychnyi ta psykhoanalitychnyi zhurnal [International psychiatric, psychotherapeutic and psychoanalytic journal, vol. 8 (3) (29), pp. 4-14, Uk.

3. Semyhina, T. Pavlenko, I. Ovsiannikova, Y. (2017), "Okhorona psykhichnoho zdorovia v umovakh viiny" [Mental health care during a war], In 2 parts, Part 1, Nash format., Kyiv, Uk. 
4. Okhlopkova, T. Batsiuk, T. (2017). “Okhorona psykhichnoho zdorovia $v$ umovakh viiny" [Mental health care during a war], In 2 parts, Part 2, Nash format, Kyiv, Uk.

5. Pinchuk, I. Ya. Khaustova, O. O. (2014). "Optymizatsiia pidkhodiv do nadannia psykhiatrychnoi dopomohy vidpovidno do suchasnykh potreb uchasnykiv boiovykh diy", Metodychni rekomendatsii, Kyiv, Uk..

6. Spinhoven, P. Penninx, B. W. van Hemert, A. M. de Rooij, M. \& Elzinga, B. M. (2014). "Comorbidity of PTSD in anxiety and depressive disorders: Prevalence and shared risk factors", Child abuse \& neglect, vol. 38(8), pp.1320-1330, En.

7. Patel, M. B. Jackson, J. C. Morandi, A. Girard, T. D. (2016). "Incidence and Risk Factors for ICU-related Posttraumatic Stress Disorder in Veterans and Civilians", AJRCCM. article in press, [Online], available at: http://www.atsjournals. org/doi/abs/ 10.1164/rccm.201506-1158OC\#.WBi0j3V97eQ, En.

8. War Trauma Foundation and World Vision International (2010). "Psychological First Aid Anthology of Resources", [Online], available at: www.interventionjournal. com/ and www.psychosocialnetwork.net, En.

9. World Health Organization (2010), "mhGAP Intervention Guide for Mental Health, Neurological and Substance Use Disorders in Non-specialized Health Settings. Geneva: WHO Mental Health Gap Action Programme”, [Online], available at: http://www. who.int/mental_health/mhgap, En. 